\title{
Urban Youth Scholars: Cultivating Critical Global Leadership Development through Youth-Led Justice-Oriented Research
}

\author{
Ayana Allen-Handy ${ }^{1} \cdot$ Shawnna L. Thomas-EL ${ }^{2} \cdot$ Kenzo K. Sung ${ }^{3}$
}

Published online: 21 March 2020

(c) Springer Nature B.V. 2020

\begin{abstract}
Educational researchers and practitioners have cited the need for new directions in youth leadership studies as it relates to globalization. Globalization is considered one of the most important economic, cultural, and social trends of the last century, yet there is much debate about the educational curricula that best support the development of global leadership in youth. Most existing global-focused programs (i.e. IB/AP) engender grave inequities in access and opportunities, particularly for urban youth, and do not often allow youth to critically interrogate the myriad injustices that plague the world. There is, however, a burgeoning body of scholarship centered on critical youth studies as a transformative process for youth development. This phenomenological case study shares the findings from the Urban Youth Scholars program, an after-school program focused on cultivating the global leadership development of five youth in the program. This study utilized a Social Justice Youth Development framework to explore the development of the youth's self, social/community, and global awareness through critical consciousness building and critical social analysis. Findings depict youth perceptions of global leadership development and include implications for scholars and practitioners for centering youth-led justice-oriented research as a tool for global leadership development.
\end{abstract}

"What is it that we owe to others because we all belong to the human community?"

Glynda Hull, Jessica Zacher, and Liesel Hibbert, 2009, p. 120.

Ayana Allen-Handy

ama433@drexel.edu

1 Department of Policy, Organization, and Leadership, Drexel University School of Education, Philadelphia, PA, USA

2 Department of Basic and Translational Sciences, University of Pennsylvania School of Dental Medicine, Philadelphia, PA, USA

3 Department of Language, Literacy, and Sociocultural Education, Rowan University College of Education, Glassboro, NJ, USA 


\section{Introduction}

Youth development in a complex, interconnected, and ever flattening (Friedman 2007) world is a topic that is steadily gaining credence across various disciplines. Educational researchers and practitioners alike have cited the need for new directions in youth leadership studies as it relates to contemporary contexts of globalization, which Hull et al. (2009) define as the "flows of capital, people, services, expertise, goods, texts, images, and technologies around the world and across national and regional borders" (p. 119). Globalization has been considered one of the most important economic, cultural, and social trends of the last century, yet grave inequalities and injustices are inherent within (De Lissovoy 2010), and history has shown us the best and the worst of the human spirit in regards to the embracement of difference across racial, ethnic, religious, gender, sexuality, and intersectional lines. One of the central challenges has been reconciling that all of humanity shares a common fate on the planet that we share (Sachs 2008), and thus, new forms of global cooperation and critical understanding of the myriad ways in which the global community is interrelated and entangled are required (De Lissovoy 2011). This ongoing shift from the individual (and his/her own) to the collective, may be quite a feat in a context that has historically and contemporarily been shaped by power, colonialism, and Eurocentrism (Tuck and Yang 2018), and even more problematic to do so within the current polarizing sociopolitical national and global context. In addition, globalization is a socially constructed, complex, and multi-layered phenomenon intended to "exasperate tensions between local and global dynamics" (Lapayese 2003, p. 493). Hull et al. (2009) foreshadow much of what we now find to be part and parcel of globalization under a Trump administration:

In the post-9/11 era, most would agree that in the United States, our propensity for welcoming interconnection has lessened; we think in terms of fissures and chasms between ideologies and cultures while globalizing flows loom large as frightening trends that might engulf us against our will, taking jobs, lifestyles, and lies rather than connecting and enriching us (p. 119).

Eighteen years post-9/11, "in country after country, the Trump administration is gutting U.S. support for human rights, the rule of law, and good governance" (Margon 2018, p. 39), while assaulting liberty and justice for all both within and outside of U.S. borders. We as a global community continue to grapple with how best to co-exist, sustain ourselves and the planet, while moreover coming together to build solutions for issues that impact us all. In this vein, Sach's (2008) warns, "we will have to pause from our relentless competition in order to survey the common challenges we face. The world's current ecological, demographic, and economic trajectory is unsustainable, meaning that if we continue with "business as usual' we will hit social and ecological crises with calamitous results" (p. 5). Although projected back in 2008, herein lies the predicament that various fields and disciplines such as the natural, physical, biological, social and political sciences, economics, the humanities, and even education are seeking to solve 
in 2020. In light of these pending challenges, The United Nations (UN) has posited the need for urgent global cooperation around issues related to global sustainability.

In 2000, the onset of a new millennium, the UN introduced eight Millennium Development Goals (MDGs). The purpose of the goals was to address the world's severe poverty through the development of a strategic focus on 1. Income, 2. Hunger, 3. Disease Control, 4. Education, and 5. Environmental Sustainability. These promises for sustainable development were to be achieved by the year 2025. In 2015, through a complex political process, the UN reconceptualized the MDGs and they evolved into the Sustainable Development Goals (United Nations 2015; Costanza et al., 2016). According to the UN's official SDG website,

The Sustainable Development Goals are the blueprint to achieve a better and more sustainable future for all. They address the global challenges we face, including those related to poverty, inequality, climate change, environmental degradation, peace and justice. The 17 Goals are all interconnected, and in order to leave no one behind, it is important that we achieve them all by 2030 (United Nations, 2020).

Likewise, Costanza, et al. (2016) summarized that the SDGs address systematic barriers to sustainable development across social, economic, and environmental domains inclusive of institutional and governance components which apply to all countries in the world, not only developing countries. The SDGs contain 17 goals, 169 targets, and 300 plus indicators, with little guidance surrounding their execution, nor how these goals can best be integrated into educational policy and curriculum. An even larger looming concern is the absolute need to acknowledge and moreover center the part that power and privilege have played in maintaining the historical, economic, and social catalysts that have contributed to sustained oppressions (and the need for the SDGS anyway) by human forces such as racism and colonization, and a lack of stewardship over our human and other capitals, as well as the impact on highly debated and contested topics such as climate change. Nevertheless, it is important to continuously grapple with the role that education might well play in this globalization discussion.

Traditionally, the goals of education have been to advance the social, political, and economic priorities of the country (Spring 2016). However, in an era of globalization, educational goals have shifted and there is some debate about what a global education means and should look like. Some argue that globalization should be the focus of curricular, pedagogical, and experiential programs in schools (Kenway and Bullen 2008), while others contend that students should be groomed to strive for cosmopolitanism and hybridization, in other words, to become a citizen of the world (Hull et al. 2009; Petriglieri 2016). Yet another body of scholars advocate for a more nuanced critical stance towards globalization studies (Eidoo et al. 2011; Lapayese 2003; Mittelman 2004). Critical globalization interrogates the patterns of domination and colonization that represent the political, social, and economic conditions of globalization (De Lissovoy 2011; Eidoo et al. 2011; Steinberg 2014). Furthermore, it supports the emancipatory 
and liberatory pedagogies that push back against hegemonic global forces (AllenHandy et al. 2019; Freire 1970; Sung and Allen-Handy 2019; Sung and Coleman 2019). Via this viewpoint, it is possible for education, "the critical, processual, improvisational practice of pedagogy, to propose an original and radical sense of global culture and society, as well as to try them out in the constellation of its own relationships, the relationships of teaching and learning" (De Lissovoy 2011, p. 1120). We agree that teaching and learning can serve as a launch pad for transformative global education, moreover, we support the ideal that youth learn through critical research about "complex power relations, histories of struggle, and the consequences of oppression" (Cammarota and Fine 2008, p. 2). In fact, youth uphold great potential to actively engage in critical social analysis and critical consciousness building particularly towards issues of social justice within a global context (Akom et al. 2008; Ginwright and Cammarota 2007; Watts and Hipolito-Delgado 2015).

In this paper, we share the findings of a two-year after-school program with five high school students who participated in The Urban Youth Scholars Fellowship Program (Urban Youth Scholars), ${ }^{1}$ a program dedicated to critical global leadership and scholar identity development (Allen-Handy and Thomas-EL 2018), with a foundational focus towards justice (Tuck and Yang 2018). Although we use urban to describe the program and our youth participants, we find it imperative to situate the way in which urban is operationalized in this study. Our use of urban rejects pejorative notions of urban space and the individuals that live and thrive in this space. Particularly, our study rejects urban as a broad brush to depict Black, Brown and poor communities (Howard and Milner 2014), and the deficit views of youth which have become pathologized and institutionalized and which often breed a type of marginalization that many youth experience; thus leading to their disempowerment (Akom et al. 2008). Rather, we adopt a vision of urban that embraces the rich possibilities of urban youth, and the salience of their agency (Allen-Handy et al. 2019; Leonardo and Hunter, 2007; Paris 2012; Sung and Allen-Handy 2019; Sung and Coleman 2019). Our participants represent various races, cultures, genders, and sexual orientations, yet it is within their urban school and our urban community in the Northeast that the complexities of our identities and experiences collide. Our program strived to more fully understand if and how The U.N. SDGs might serve as an entry-point to merge the worlds of critical globalization education and critical research towards transformative youth global leadership development, particularly in light of decreasing acceptance, tolerance, and justice across difference. Thus, this paper seeks to contribute to an emerging body of research which is employing a critical stance within the nexus of urban and global education, to facilitate youth empowerment and ultimately justice-oriented global leaders.

\footnotetext{
${ }^{1}$ Urban Youth Scholars is a pseudonym for the program.
} 


\section{Conceptual Framework}

There is no future of the field of education without the contributions of people who are doing their work under the rising sign of social justice. There is no legitimacy to the field of education if it cannot meaningfully attend to social contexts, historical and contemporary structures of settler colonialism, white supremacy, and antiblackness. Social justice is not the catchall; it is the all. Eve Tuck and K. Wayne Yang, 2018, p. 5

Tuck and Yang (2018) remind us that social justice is not a catchall, but the all that is necessary in the field of education but moreover for a more just way forward. Even still the question remains, "towards what justice" (p. 11)? In this vein, crafting and maintaining a justice-oriented disposition requires the understanding that inequities are structured, power is asymmetrical, and that transformative change is needed in order to cultivate different educational outcomes (Oliveira Andreotti 2014; Tuck and Yang 2018). In more deeply thinking about the development of urban youth's critical global leadership development, we drew from literature in critical globalization education, global leadership development and youth agency, as well as a social justice youth development theoretical framework to guide our understanding of urban youth's justice-oriented global leadership development.

\section{Critical Globalization Education}

There is much debate about the need for, requirements of, and who should have access to global education in an increasingly globalized, albeit polarized, society. Global education emerged in curriculum in schools in the 1970s and prioritized nationalistic educational curriculum that followed the economic trends which favored U.S. interests (Myers 2006; Myers and Zaman 2009; Parker et al. 1999; Thornton 2005). In this vein, global education supported the development of an industrial workforce that would position the U.S. as a dominant leader and world power (Baumol et al. 1989; Burnham 1993; Carl 2009; Jensen 1993). Global education has also been conceptualized in ways similar to international education, multicultural education, peace education, and human rights education (Rapoport 2010). More recently, global education has evolved into global citizenship education with its focus on developing cosmopolitans: empathetic "good citizens" who desire to "help" the less fortunate by becoming "culturally aware", well rounded individuals (Davies 2008; Petriglieri 2016). Yet and still, the field has not come to consensus on what it really means to be a global citizen, and even more so, unsure of its execution within classrooms. Curricular tensions between crystallizing a national identity including patriotism towards the nation-state and developing a global citizenry permeates schooling, leaving teachers with the burden of trying to balance the two (Rapoport 2010).

A global citizen education predicated on developing cosmopolitans and hybrid citizens, has traditionally been accessible to White, middle and upper-class students who attend elite suburban and independent schools. Herein, their access 
to IB and AP programming includes educational experiences which emphasize critical thinking, project-based learning, international experiences abroad (Culross and Tarver 2011; Hill 2012; Hill and Saxton 2014), and various opportunities to earn college credit (College Entrance Examination Board 2012; Hallett and Venegas 2011; Taliaferro and DeCuir-Gunby 2008). Such opportunities to experience a global citizen education are few and far between for marginalized Black and Brown youth in under- resourced urban schools. Rather, urban schools are often stifled by neoliberal policies and practices that institutionalize standardized testing, accountability, and systems that maintain the school to prison pipeline (Lipman 2013). The nexus of urban education and global education is blight with inequities, accruing compound interest on the education debt (Ladson-Billings 2006), and omitting justice-oriented educational experiences (Hughes 2011; Sung 2014). Davies' (2008) assertion that "outrage" is what is needed in order to espouse justice, is a position taken up by critical globalization education and one in which could be applied to urban schooling.

Critical globalization education, which Lapayese (2003) contends challenges dominant ideologies, disassembles hierarchies of power, and allows both teachers and students to question curriculum and pedagogies that do not do so, provides an important point of entry for justice-oriented global education. Likewise, Eidoo et al. (2011) define critical global citizenship education as:

....an agenda for a social-justice oriented approach to teaching and learning global issues in the classroom, in so doing students are encouraged to adopt a critical approach to how they and their nation are implicated in local and global problems, to engage in intercultural perspectives and diversity and to recognize and use their political agency towards effecting change and promoting social and environmental justice (p. 61).

Oliveira Andreotti (2014)'s work found that most contemporary global education curriculum did in fact omit a critical analysis of economic and cultural roots of the inequalities in power, wealth, and labor distribution, which leads to a few powerful nations maintaining "globalizing powers", while others remain "globalized" (Shiva 1998). De Lissovoy's (2010) push to move from globalization to an ethical democratic globality, underscores the need for globalization education to recognize relations of power, how they have shaped our global history, and perpetuated epistemologies of domination enacted in the constellation of colonialism and Eurocentrism. In Rapoport's (2010) study, findings indicated that teachers lacked confidence to teach critical globalization education and that teachers needed more rigorous professional development and guidance to incorporate it systematically into curriculum instead of isolated throughout. Likewise, Mikander (2016) highlighted the need to tackle global inequality through acknowledging that globalization is a continuation of colonialism, and advocating for teachers' access to curriculum and materials that encourage students to ask critical questions about the forces of globalization. In tandem with the field of critical youth studies, it is important to understand how the extant literature has responded to the development of youth as critical global leaders. 


\section{Global Leadership Development and Youth Agency}

"Global" represents various definitions and is often interchangeable with words such as international, multinational, and transnational. Meanwhile, the extant literature has attempted to identify core competencies of global leaders in order to better understand how best to develop them for the future. Despite variations within the definition of global, and the challenges with articulating a universally accepted global leadership framework (Mendenhall et al. 2012), scholars have arrived at consensus that the competencies that successful national leaders possess, serve as foundational components for the development of global leaders (Adler and Bartholomew 1992; Brake 1997; Goleman 1998; Gregersen et al. 1998; Harvey and Buckely 2002). For instance, the global leadership development literature is divided between competency models (Bartlett and Ghoshal 1987; Dorfman 1996; Jokinen 2005; Morrison 2000) and contingency theories (Reiche et al. 2017).

While competency models consider the characteristics that a global leader might possess, frameworks based upon contingency theories pertain to the way that one's environment or contexts may dictate how these characteristics are operationalized. Within the competency literature, Brake (1997) articulated three competencies, which are referred to as the "global leadership triad", and each triad includes five separate components: (a) relationship management (change agentry, community building, conflict management and negotiation, cross-cultural communication and influencing); (b) business acumen (transition from local to global, entrepreneurial spirit, professional expertise, stakeholder orientation, total organizational astuteness); and (c) personal effectiveness (accountability, curiosity and learning, improvisation, maturity, and thinking agility). Conversely, Jokinen (2005), offers a global leadership framework that includes: (a) foundational characteristics (i.e. selfawareness, ongoing personal transformation, and inquisitiveness), (b) mindset characteristics of (i.e. optimism, self-regulation, social judgement, empathy, determination to work in international environment, cognition, and acceptance of complexity and contradiction), and (c) behavioral characteristics. According to this framework, global leaders are scholars who quickly adapt to new or unfamiliar environments. Although, contingency theories focus on the contexts that cultivate global leaders (Bartlett and Ghoshal 1992; Mendenhall 2006), neither competency nor contingency frameworks enact critical perspectives that include social justice as a foundational tenet for global leadership development. This renders the need for a more nuanced critical examination of global leadership development, inclusive of critical race analyses (De Lissovoy and Brown 2013; Weiner 2012) and critical youth studies (Ibrahim and Steinberg 2014).

Critical youth studies suggests that the challenges young people experience within their local communities, are important training grounds for the development of global leadership (Allen-Handy and Thomas-EL 2018; Checkoway 2011; Finn and Checkoway 1998; Zeldin et al. 2017). Youth are direct heirs of their communities, and they have critical knowledge and skills derived from their lived experiences that have the power to transform their communities. Unfortunately, traditional views of youth, in particular urban youth, focus on pejorative perspectives (Akom et al. 2008), and often strip them of their agency to respond to issues that directly 
impact them. On the contrary, a burgeoning body of literature highlights the salience of granting youth opportunities to engage in critical research and critical social analysis in order to interrogate the systems and structures that impede justice within and outside of their communities (Flanagan and Levine 2010; Hipolito-Delgado and Zion 2017; Kirshner 2015; O’Donoghue et al. 2002). Ultimately, this critical consciousness building "enables students to act and live in ways that enable the betterment of themselves and society as a whole" (Karvelis 2018, p. 46), and supports the development of mindsets that in the words of Martin Luther King Jr., bend towards justice (Allen-Handy and Thomas-EL 2018).

Critical global leadership development can be supported by cultivating a third space (Soja 1994) between home, school, and other local contexts which provides opportunities for youth to develop agency and to be empowered to interrogate injustices that they experience and witness in their communities (Allen-Handy and Thomas-EL 2018; Allen-Handy et al. 2019; Baldridge et al. 2017; Conner and Rosen 2016; Ginwright 2004; Kirshner 2015; Sung and Allen-Handy 2019; Sung and Coleman 2019). For example, elements of youth activism and critical research have been noted to be essential for youth to develop critical consciousness and leadership capabilities. (Cammarota and Fine 2008; Dolan et al. 2015). Furthermore, today's youth are digital natives whose exposure to world affairs through various technological platforms and applications, equip them with global perspectives that help them internalize that inequities they witness in their everyday lives are shared globally and emanate from similar structures of power and ideologies of White supremacy. Moving beyond conceptions that individuals must speak for the majority, urban youth are determining that "ordinary people are better equipped to solve their problems than authority figures or experts" (Longo and McMillan 2015, p. 73), and that they are the leaders and change agents to do so.

The active, agentic participation of youth in developing solutions for societal ills, is an effective antidote for what De Lissovoy (2012) defined as the colonial impact of the American model of education. More importantly, encouraging their input fosters a platform from which they can identify and openly challenge the underlying causes of "social, economic and political factors including race, gender, class and cultural" (Iwasaki 2016, p. 268) marginalization. The ability to challenge these issues also means that new knowledge (Powers and Allaman 2012; Mittelman 2004) will emerge, and that youth will uphold solutions to address current conditions. These are much needed perspectives in critical global leadership development, whereby the foundation of justice will enable youth to see beyond the immediacy of their locality, to consider the global impact on similarly marginalized communities across the globe.

\section{Theoretical Framework}

In the project of developing justice-oriented global leaders, we situate this work within a Social Justice Youth Development (SJYD) theoretical framework (Cammarota 2011; Ginwright and Cammarota 2002; Ginwright et al. 2005). Inherent in a SYJD is a critical disposition that interrogates power and privilege, the permanence 
of race, and other intersectional aspects of critical race theory (Hughes 2011; Weiner 2012). We found utility in employing this framework, for it promotes the praxis of integrating critical consciousness and social action which help youth interrogate some of the root causes of social and historical inequities that perpetuate issues that they experience in their own lives. Not only does building their capacity to do so transform their own lives, but also the very communities in which they live (Ginwright and Cammarota 2002). SJYD praxis builds youth awareness at the levels of self-awareness, social/community awareness, and global awareness so that they can better understand how exploration of their own identity in terms of their race, class, gender, sexuality, etc. may be influenced by privilege and even oppression through power. The next level of social awareness or community awareness (Cammarota 2011) supports their critical consciousness building about their own community issues through the development of research and problem-solving skills. Ultimately what is hoped for in SYJD is that students reach the level of global awareness.

Global awareness is where they build complete praxis as they employ critical reflection to better understand the connections between their own impediments and those faced by people all over the world. This includes an analysis of historical forms of oppression such as capitalism and colonialism, white supremacy, and patriarchy as well as fostering youth's capacity to demonstrate "connectedness with others, empathy with suffering, and resistance to oppression" (Ginwright and Cammarota 2002, p. 90). This critical civic praxis formation inspires youth's social justice orientations and activism (Ginwright and Cammarota 2007). Figure 1 depicts our conceptualization of the various levels of a SJYD framework that might at first glance be viewed as a linear, upward trending process. However, we want to reiterate that this process is a 360 degrees approach where one can go up or move down vacillating back and forth through the various stages as needed and as so warranted throughout the development process. The final goal of obtaining a social justice youth development framework is a cyclical process and makes room to explore the various levels in iteration.

\section{Methods}

\section{Program Background}

The Urban Youth Scholars was a two-year after school program in an urban intensive (Milner 2012), diverse high school in the Northeast wherein the student demographics include 36\% Black/African American, 34\% White, 12\% Latinx, 11\% Asian, and 7\% Multi-racial. Our project included five students who participated during their junior and senior years of high school. The purpose of the program was to support the development of critical scholar identities (previously published in Allen-Handy and Thomas-EL 2018) as well as to support their global leadership development towards justice both within and outside of our local community. The Urban Youth Scholars program was created using frameworks of culturally affirming, relevant, responsive, and sustaining pedagogies (Allen, et al. 2013; Gay 2010; Ladson-Billings 1995; Paris 2012) and moreover sought to highlight local injustices 

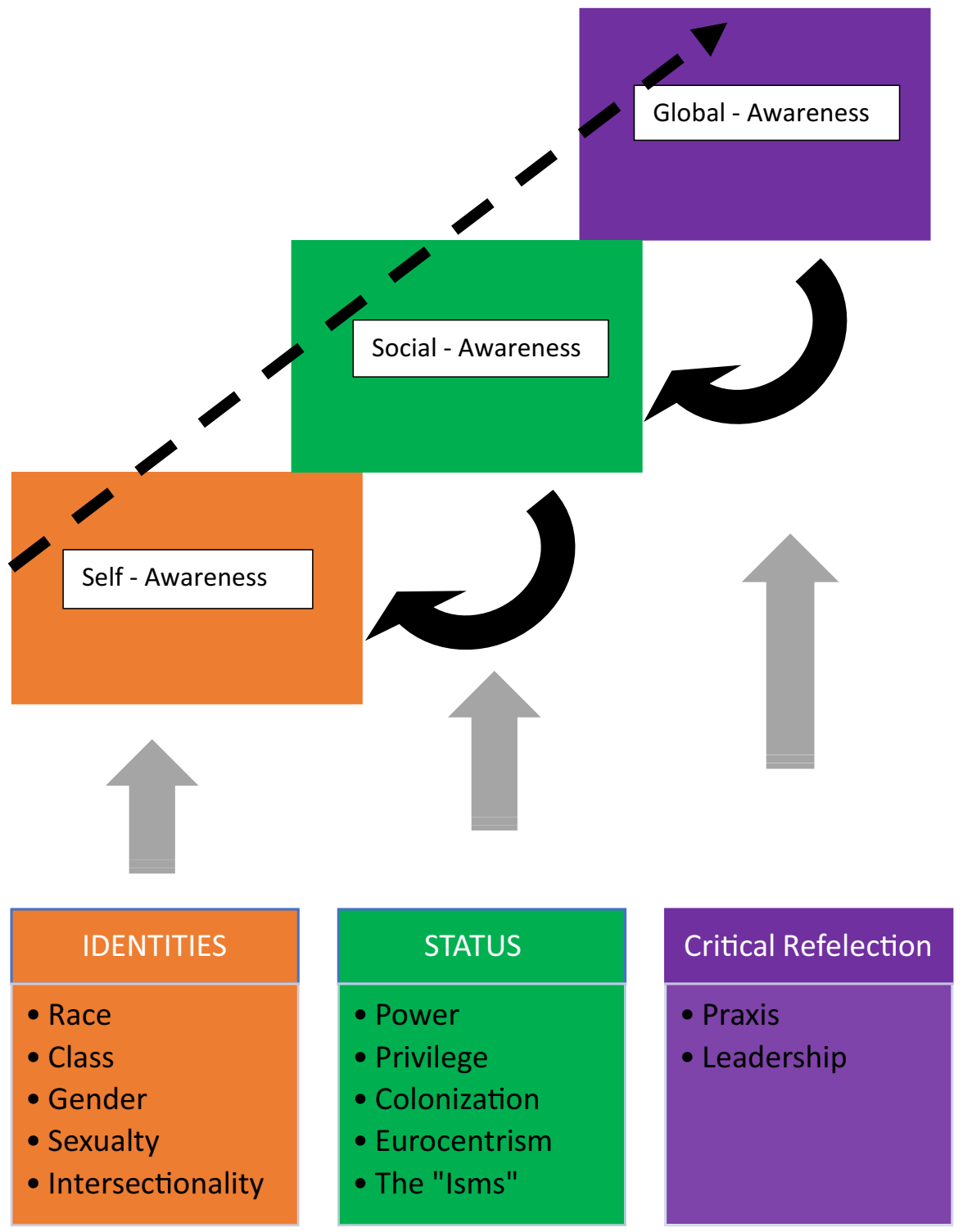

Fig. 1 Conceptualizing a social justice youth development framework

and inequities within our immediate community in order to build their critical consciousness and critical global perspectives. Each week of the program we engaged in participatory and collaborative examinations of our own life experiences and how these experiences connected to broader issues in the world at the intersections of historical, social, political, racial, and economic contexts of urban communities more broadly. This scaffolded approach set out with the intention to develop their cultural, community, and social awareness to be later applied to critical analysis of globally 
shared connections of oppression (Murray and Milner, 2015). Not only did we focus our collective energies and learning experiences on issues alone, but our work was primarily solution driven. We learned about the "scientific process" and how best to dismantle normative conceptions of who a scholar is, traditionally relegated to White men, and how their positionality as urban youth did in fact situate them as experts of their own experiences and the experiences of others in their communities. Students also learned about diverse ways of knowing particularly how critical race theory inclusive of BlackCrit, LatCrit, QueerCrit, intersectionality and critical race feminism are an important foundation for critically examining these issues. After several lessons and experiences of the aforementioned, students were encouraged to choose one or several U.N. Sustainable Development Goals to develop a research project grounded in a critical/justice-orientation including social, environmental, health, etc. After two-years of research, writing, and supporting one another, students presented their work as the featured presenters at an international conference in Puerto Rico, as well as back home for our local community. Students also participated in critical civic praxis endeavors at two local schools in Puerto Rico.

\section{Participants}

The participants in this study were five youth scholars (Arielle, Evelyn, Inez, Jacob, and Thomas $)^{2}$ who participated in the Urban Youth Scholars program during their junior and senior years of high school. Each student was asked to share more about his/her/their self, which we share in Table 1.

\section{Positionality}

We also find it important to frame our own positionality. We come to this work in the role of founder/director (lead author) of the program, graduate assistant (second author), and data analyst (third author). The lead and second authors worked closely with participants throughout the two-year program and met with them once a week in person (as needed virtually), and several times a week as we prepared for the conference. We positioned ourselves as adult allies with the youth researchers, mentors and collaborators. Therefore, we engaged in ongoing reflexivity to manage our own potential biases throughout the research study keeping in mind our subjectivity in relation to the participants. The third author supported the data analysis process and supported this research project by helping the team critically examine our weekly practices and lessons with students, as well as the ways in which the experiences that were afforded students in our program were remaining true to a social justice youth development framework. All three of us consider ourselves to be critical scholars in our own right and are deeply committed to issues of justice and the emancipation of oppressive pedagogies and methodologies that maintain the status quo in the researching of traditionally marginalized participants. Therefore, our own intersecting identities as Black women (lead and second author) and an Asian

\footnotetext{
2 All names are pseudonyms to maintain participants' anonymity.
} 


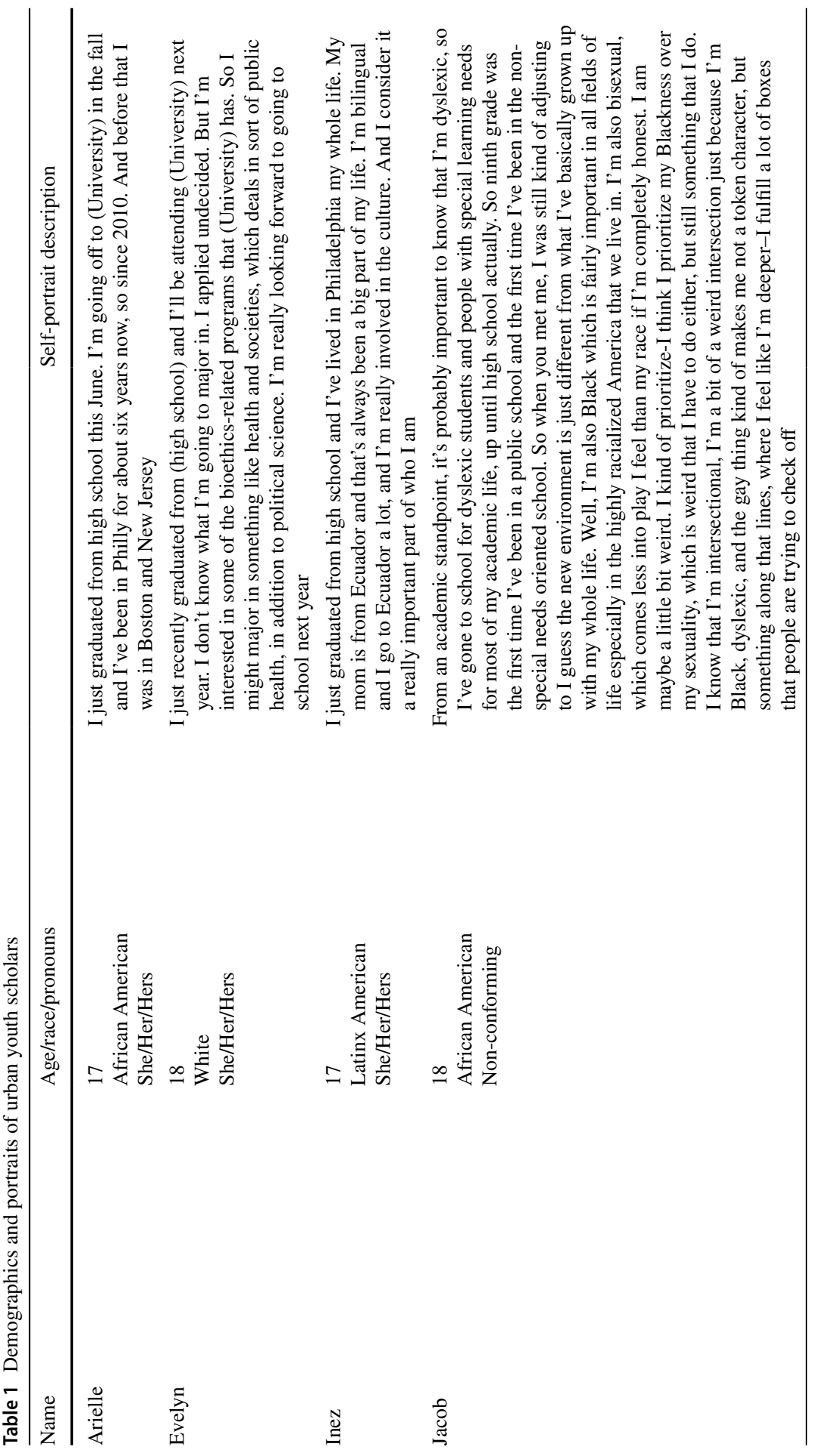




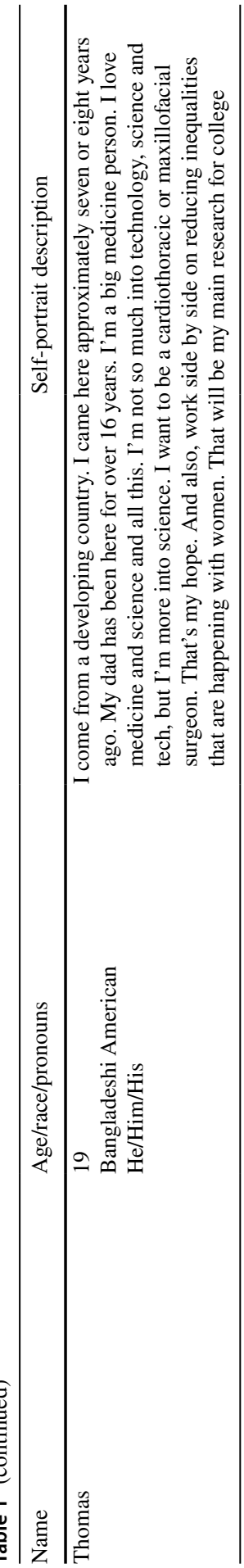


American man (third author) are essential in shaping our own world view, ontologies, and epistemologies.

\section{Research Design and Research Question}

Our research design was situated within both a constructivist/interpretive and critical paradigm as we were most interested in the students' construction of meaning as well as the ways in which knowledge and one's reality is socially constructed and influenced by power. We believed that these ontological and epistemological viewpoints could be best examined through a qualitative tradition, to generate understanding around the fundamental characteristics of urban youth global leadership development (Usher and Jackson 2014). Therefore, this study used a phenomenological case study design to examine how the youth researchers developed critical global leadership and their perceptions of this experience within a critical research fellows after school program. Phenomenology explicates the students' experiences by centering their own accounts of phenomenon derived from their own lived experiences (Henderson et al. 2018; Miller and Salkind 2002). We were most focused on their own perceptions and their meaning making processes (Creswell 2013), and phenomenology allowed for the internal processing of first-hand experiences to shape the students' perceptions (O'Leary 2007), thereby validating their perceptions as essential knowledge. The research question that guided this study was:

How does youth-led justice-oriented research on issues related to the UN Sustainable Development Goals support urban youth's critical global leadership development?

\section{Data Collection and Analysis}

This IRB approved study gathered informed consent from all participants before data was gathered. Data was collected through audio-recorded semi-structured interviews, and interview questions were developed to support a storytelling environment, garnering answers about participants' experiences in the Urban Youth Scholars Program. All interviews took place in the PIs office at her institution during the summer after the students had graduated from high school ( 2 academic years since the program's inception). Upon collection of data, interviews were transcribed and analyzed using the following inductive and multilayered analysis process. First, we read all transcriptions in their entirety and applied a holistic-content analysis (Lieblich et al. 1998) to gain a global impression of each interview. Next, we individually employed open coding to identify emerging patterns in the data and then axial coding to identify sub themes (Corbin and Strauss 2008). After we each settled on our individual codes, we engaged in a collaborative and reflexive iterative process. This process did not execute a repetitive and mechanically driven analysis, but instead we engaged in a reflexive process of visiting and revisiting the data in support of our insight into the data and our meaning making processes (Srivastava and Hopwood 2009). This stage of data analysis included multiple rounds of member 
checking where we communicated often with the participants to help us make meaning of the data, and to ensure our interpretations of their meanings were correct. It was important to us that we represented the participants and their voices as they had intended. Then we identified common themes and subthemes across all narratives to which we formulated meaning through the clustering of the themes (Creswell 2013). Lastly, we integrated the clustered themes which then led to the emergence of the study's findings.

\section{Findings}

"The matrix out of which powerful decisions are born is sometimes called racism, sometimes classism, sometimes sexism. Each is an accurate term surely, but also misleading. The source is a deplorable inability to project, to become the 'other', to imagine her or him. It is an intellectual flaw, a shortening of the imagination, and reveals an ignorance of gothic proportions as well as a truly laughable lack of curiosity". Toni Morrison 2019, p. 43.

As the beloved late Toni Morrison quote above highlights the importance of sincerely striving to become 'the other', Urban Youth Scholars intentionally sought to cultivate the curiosity required to project and eventually become the other through a SJYD framework. The three study findings of (1) towards a conception of we, (2) crossing borders and pushing boundaries, and (3) UN SDGs and critical global leadership development highlight the students' perceptions of their global leadership development in the Urban Youth Scholars program.

\section{Towards a Conception of We}

From the onset, the conception of we was nurtured amongst the group by creating a safe, shared space and building rapport in order to foster a community of scholars. Over time we began to trust one another, unpeel more and more layers of ourselves, and build authentic relationships throughout the two-year program. This crystallization of trust and our relationships with each other was essential for us to engage in the interior self-work needed for critical consciousness building towards the development of social justice youth. Within our shared space, various aspects of the SJYD framework supported students' self, community, and global awareness. Through multiple activities and discussions, we interrogated the place that power and privilege have played in maintaining the status quo in our lives, the community, and the global community more broadly. We shared how various isms (racism, sexism, classism, homophobia, etc.) have directly impacted our own lived experiences and those within our communities of affinity. These inquiries engendered dialogues about the importance of locating oneself and our individual experiences to move towards a conceptualization of we. We engaged in several reflective activities that supported students' understanding of the various aspects of their lives that are most salient in their development and the shaping of their identities, particularly as it relates to their local context. We wanted to 
center their most proximal relationships and the institutions in which they frequently encounter (i.e. home, schools, churches, etc.) as contextual influences. For example, one of the activities we engaged in was for students to draw from their own Bio-Ecological Systems (Bronfenbrenner 1979) to situate themselves in their local context so they could visualize how the various spheres of influence (micro, meso, exo, macro, and chrono systems) impacted them specifically. When asked to describe lessons or activities that had an impact on their global leadership development in the program, Arielle notes, "I like the circle one we did with the family circle, with the different layers of the circles and getting further and further away from myself and how they affected me".

Jacob agrees,

It was the one with the spears in it, about how things relate to you as an individual, how information relates to you as an individual. I remember that one thoroughly. It was one of the most informative ones for me because this was a completely new thought game to me, and I thought it was very interesting.

Overall, our curriculum and lessons were designed for students to start from a place of self-analysis and self-appreciation within a SJYD framework. This was then used as a launching pad to spark their curiosity and to nurture their own cultural competence to foster critical consciousness building (Ladson-Billings 1995), and a greater critical social analysis (Ginwright and Cammarota 2002). Inez recalls being awakened by a discussion on equality versus equity and noting that this was something that "we never talked about before in school".

Thomas shares,

The lessons were very intriguing because from one session to another, we learned something new every single day. You guys brought new topics, new ways to research our ideas that we hadn't thought about before.

Our ongoing conversations and discussions around a variety of topics helped to orient students' understanding of our global interconnectedness and shared experience through our common humanity. These courageous conversations contextualized the ways in which the local and global are connected and even more so in our digital world, interconnected across shared experience, shared hopes, and dreams for justice across difference. This conception of we is further illuminated by Arielle:

Researching a subject like food deserts is kind of like a global situation, even though I focused only in America, there are other places in the world where these people are facing the same exact problems. So being able to present in Puerto Rico to people who are around the country and around the globe, it kind of gives them-it opens their eyes to it. Because people don't really think about it as much. So, I think being able to advocate for such a problem was a good way to kind of become a global leader. 
The issue of food deserts and food insecurities are characteristic of disadvantaged communities where the health and nutrition of racial minorities are devalued (AllenHandy et al. 2019; Sung and Allen-Handy 2019; Sung and Coleman 2019). Arielle's ability to position herself as an advocate to address this problem as one who has witnessed this problem in her own community and throughout the U.S., connects to the various other places around the world that too may struggle with food insecurity, and paints a beautiful picture of how Arielle and the other students were internalizing and more deeply understanding the connections between the local to the global; in a sense from the me, to the we. As students moved along the continuum to this conception of we, the theme of crossing borders and pushing boundaries emerged as another important finding in the youth's critical global leadership development.

\section{Crossing Borders and Pushing Boundaries}

One of the major patterns observed in the data depicted students' various pathways and entry points into more deeply understanding the we within a global context. Within all of their narratives, there became a point at which they found it to be essential to cross over into new and unfamiliar territories to more deeply understand themselves, their positionality, the issues they were researching, and the intersecting global implications. This crossing of borders and pushing of boundaries was indicative of stepping out of their comfort zones, collaborating across disciplines and affiliations, making connections concerning the inter-connection of global experience, as well as the literal crossing of borders to travel to Puerto Rico including all of the preparations to do so, and for a few of them traveling outside of the U.S. for the first time. For example, Evelyn shares the need to stretch herself beyond what she has access to in her school; for her the opportunity itself presents the opportunity for her to expand beyond pre-established borders:

I feel like this program was a good opportunity for me to stretch my research skills outside of the classroom because we're not always-sometimes, we're limited to a topic in school and I really wanted a chance to research more before I went to college. And so, this was a good place for me to stretch those skills and learn about new stuff. I think in addition to all of this, the Puerto Rico trip was interesting in a lot of ways. I think I definitely got to experience being in San Juan, being exposed to another culture because although Puerto Rico is a part of the United States, I've never left the continental United States before.

Evelyn's crossing of borders encompasses a literal border crossing while leaving the continental U.S. borders for the first time in her life. In a similar vein, Inez describes how she had to come completely out of her shy shell to participate in the program and to engage in the research processes. She noted several times that this was something she hadn't done before, indicating the need to push the boundaries of her fear of public speaking:

I had never had the opportunity before and to present my research was hard for me, but a really good experience because it's completely different than anything I've ever done before. And it helped me grow and become more 
confident in my abilities to present my own ideas because I'd never had to do that before in front of real professors and adults because that's not something you learn in high school, really.

Thomas expressed in his own words how "awesome" he believed the program was for pushing him outside of his own borders as it related to collaborating with others in different disciplines and affiliations, especially in reference to his topic of young girls and childhood marriage:

You get to go outside of yourself and meet with new people and tell them the topic you're researching rather than staying in your community...in your own borders and the ideas don't spread that quick if you're in just one community. So, I thought going out and letting people know about this epidemic will actually help for the idea to spread around so other people also can take on my idea.

....and when asked what constitutes a global leader, Thomas again makes note of crossing borders:

A global leader is someone that is a leader on the global scale. That their impact can be felt, not just within the borders of their communities or their state. I never thought of going outside [City] to present anything. But it was kind of shocking for my parents. They didn't want me to go that far. But it felt really good. Because when I hear the term international, I hear more ethnicities and more people of color coming in and joining the idea, rather than people that are used to it all the time. Like I've mentioned, it helps the idea get to more people rather than staying in one boundary.

Jacob depicts his process for making connections within his research, and how he grappled with the interconnectedness of seemingly unrelated topics. It is his willingness to push boundaries that illuminates his trajectory through the social justice youth development framework. We find it important to share how he interrogates his topic specifically (first quote below) and moves into a more expansive place of reflection about his critical global leadership development (second quote below).

Jacob \#1.

I wanted to research something that was honestly all too obscure. I wanted to connect a social issue to an astronomical issue, something to do with space, which seemed like a long shot. And then my research proved that it was a long shot. So, I decided to move towards the ocean because I have kind of reoccurring interest in subjects of oceanography and marine biology. And it seemed to me, there was a very clear intersection between, even past just economics and culturally between marginalized groups of people and the ocean, from Afro-Caribbean people to I think people who basically depend on the ocean as an economy local level because the oceans or water systems are interconnected. It seems like it would relate to me as someone in the city because people in cities don't seem to consider their impact on oceans, especially when they're not near water, when they're landlocked. 


\section{Jacob \#2.}

Always consider the broader scope of things, as opposed to anecdotal evidence is easy to come up with. And although it definitely has a place in your research, as it relates to you, you have to understand that it can't be the basis of your argument. You can't just talk about how things impact you specifically or your personal experience with things just because it's kind of like fluff and it's easy to sift through. A global leader is someone who considers the impact throughout the intersecting global community of various actions and I guess circumstances and phenomena and how they impact them and decide to take initiative in that for the betterment of a global, large-scale community. Just being willing to try new ideas and test all of the boundaries and all of the options.

Arielle's narrative indicates how her research had a more long-term positive implication as she furthered the study of food deserts for her senior project and college application essays to what she believes pushed her over the boundaries for college.

It was a good opportunity for me to do [the program] for my junior and especially for my senior year. Just to be able to get this practice as well is like learning new techniques for research or for presenting in public space. I furthered it in my senior year project in a lot of college applications and I think that kind of is one of the things that kind of set me over the edge is that I had this initial experience now, so I can do something similar to this in college.

The theme of crossing borders and pushing boundaries ran strong throughout all of the youth narratives and represents the salience of these themes for their critical global leadership development.

\section{UN SDGs and Critical Global Leadership Development}

By introducing students to the UN SDGs, their history, and purpose as expressed by the United Nations, we sought to further deepen students' internationalization of the interconnected "we" of humanity around the world, as well as how the goals could serve as a centering point upon which we could critically examine local and global issues and reprise solutions. Students were asked to thoroughly read and research all of the goals and choose a goal or set of goals that ignited their passion, and that they would center their research on throughout the program (Table 2). In so doing, they then chose a topic within the goal to research and particularly one that impacted their local urban community. When we asked, "How have the UN SDGs helped you see yourself as a global leader?" They were unanimous in their agreement that the UN SDGs were important and impactful in helping them develop their stances as global leaders committed to various platforms of justice. Inez replied,

I think it was important to learn about the goals, because I didn't really know that much about them before, and then to start engaging with them. And once I'd learned specifically about mental health and connected it back to people, I could see ways that each person could maybe try to help with any of those 


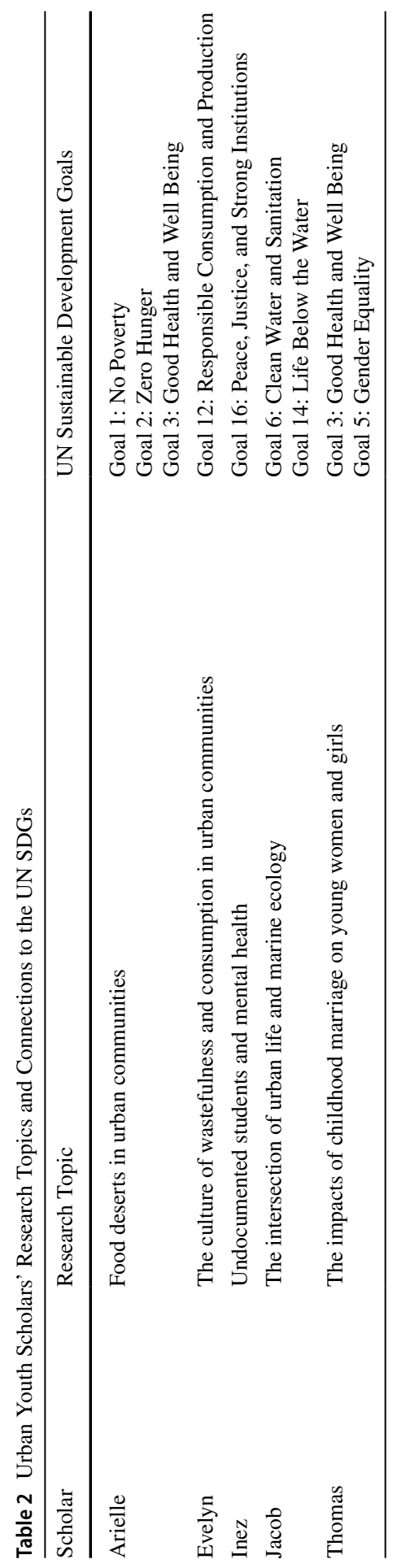


goals by doing research or doing something simple like volunteering. That could help in a small way at least.

Evelyn's enthusiasm for the goals was palpable. She noted that she had heard of them before our program, but in no way had a deep understanding of their implications for research and global leadership. She shares,

I remember being really interested in the UN Sustainable Development Goals. At first, I wasn't actually aware that that's what the program was going to be focusing on. And so, I was actually really relieved to have a more focused thing to do my research on because I was kind of like: Well, I'm interested in music, but I'm also interested in art history, and I'm interested in science. But after looking at the UN Sustainable Development Goals, I remember feeling more focused and more prepared to do research. And I think that my overall experience was definitely-I mean I think I read not the full books but so many parts of books in researching the UN goals, that I think I got a real taste of...I'm sure it's nothing compared to what professors and doctors do when they're researching, but I think I got a taste of it and that was really exciting. I have more thoughts about what I really care about, which is why I'm really glad that I became more acquainted with the UN Sustainable Development Goals. Because I've always sort of thought whatever I do with my life, with my career, I want it to help others and impact the world for the better. I think I better understand how I can do that now. But from the standpoint of research.

What Evelyn alludes to is that she feels more focused and prepared to do research through her own deeper understanding of the goals. She also has expressed that the goals helped her streamline her research interests and her points of impact. She had to accept that there were many topics that she is interested in, but realized she had to narrow down her focus. This focus led Evelyn to better understand her own passion about the issues she chose to research and the ways in which she could now ignite that interest in others. Most impressive is the fact that she connected how the goals have helped her to shape how she hopes to impact the world for the better and become a leader in the future. Inez also notes how she connected her own passions and future aspirations to the goals:

So, in the beginning when I was choosing my UN SDG, I knew I wanted to do something that involved either health or women's rights because I'm kind of thinking of going into something involving health in the future. So, then my dad gave me this article to read about undocumented immigrants and how they face anxiety and depression over the college application process. So, I read that article, and I decided that I wanted to focus on that.

We did find that the goals alone did not explicitly center the socio-historical, political, and cultural contexts that have perpetually contributed to the disinvestment and hardships faced in relation to the goals throughout various places and for various people groups around the world. Much of the critical social analysis work and interrogation of concepts such as power, hegemony, and "the isms", came from other components of the curriculum. But, what the UN SDGs did do was support students' 


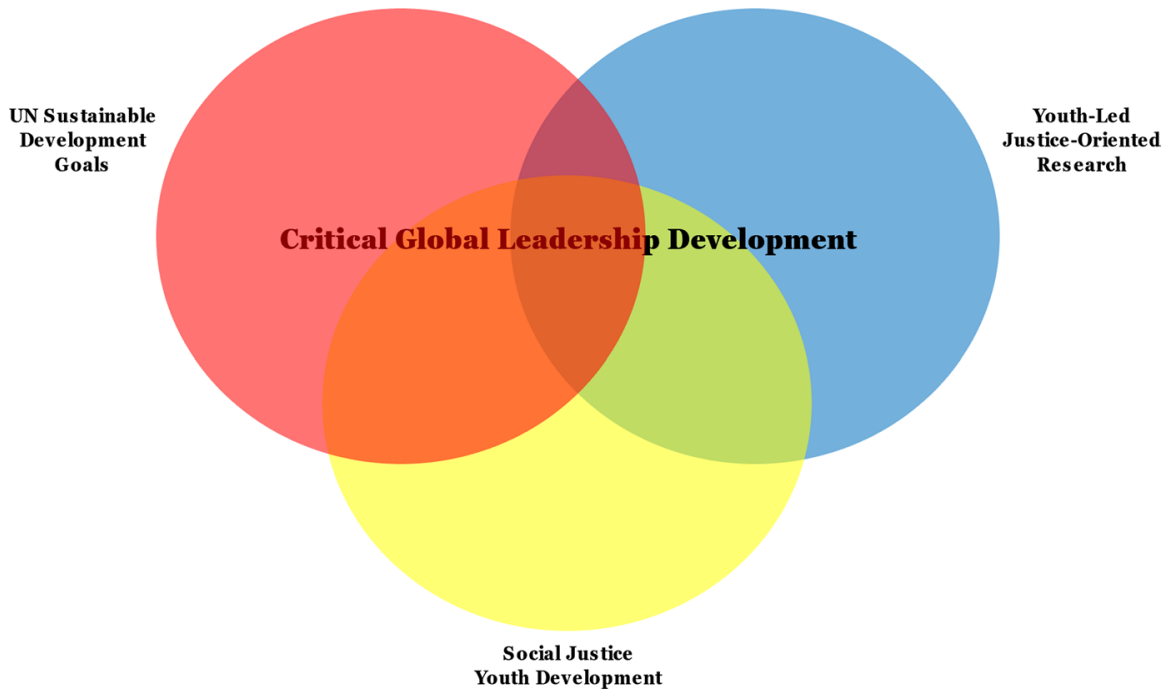

Fig. 2 A framework for critical global leadership development

sense of agency through giving them common language to more deeply understand the underlying issues and to provide their own solutions to tackle them. Overall, we found that the integration of the SJYD focused curriculum, employing youthled critical research, and the UN SDGs together formed a strong foundation for the development of the youth's critical global leadership (See Fig. 2).

\section{Discussion}

Our findings highlight the perceptions of five youth researchers in the Urban Youth Scholars program, a program which sought to support their critical global leadership development through a SJYD framework (self-awareness, community awareness, and global awareness), by engaging in youth-led critical research of the U.N. SDGs. By grounding the program and study within a SJYD framework, students were able to critically reflect upon their self-identities and experiences to develop a deeper understanding of how various interconnected spheres in their lives impact them (in)directly. Once an emerging understanding of their own ecological systems was established, and their self-awareness was cultivated, they were better able to make connections across other contexts and communities; towards a deeper global understanding of "the other" and towards a conception of "we". This "weakening of boundaries" (De Lissovoy 2011, p. 1122) by affording them the opportunity to push out of their comfort zones both intellectually as they engaged in critical research, and also by presenting their research to international and local audiences, helped them intuit that they were in fact developing as critical global leaders.

This continuous cycle between self, community, and global awareness was instrumental in fostering their critical global leadership development. 
Furthermore, it supported the development of critical social analysis (Bird and Mendenhall 2016; Murray and Milner 2015) critical consciousness building (Watts and Hipolito-Delgado 2015), psychological empowerment (HipolitoDelgado and Zion 2017), as well as their agency (Akom et al. 2008). The extent to which they were able to internalize their potential impact on their local community through more fully understanding their own lived experiences and identities served as a prelude to their perceptions of their potential impact within our global community and their global leadership potential in general. (Kets de Vries and Florent-Treacy 2002; Osland et al. 2012). These findings align with Osland et al.'s (2012) findings that global leaders are a distinct type of leader that can break through compartmental and localized perspectives to gather a deep understanding of the interconnection between the local and global in terms of both an individual's decisions and actions on the global community writ large.

The focus on youth-led justice-oriented research guided by the UN SDGs supports Cammarota and Fine's (2008) assertion that youth and in particular marginalized youth, have the capacity to " re-vision and denaturalize the realities of their social worlds and then undertake forms of collective change based on the knowledge garnered through their critical inquiries" (p. 2). In this study, time and again participants shared how taking the lead on researching critical issues such as food deserts, undocumented students mental health, childhood marriage, and other issues of social and environmental justice, helped inform their ways of knowing and being to challenge the status quo (Ginwright et al. 2005). This youth-led critical research approach, supports existing and emerging scholarship that finds Youth Participatory Action Research (YPAR) to be an important platform to build youth agency and leadership (Caraballo et al. 2017; Dolan et al. 2015). Although our project did not focus on foundational dimensions of YPAR such as the iterative integration of research and action and the co-construction of research questions and shared ownership of the research process (Ozer et al. 2010), our project did support tenets such as youth generated and executed problem identification, research and plan development, collection and analysis of evidence, reflection and sharing of findings (Burns et al. 2012). The Urban Youth Scholars cultivated a community of scholars while students had agency over the topics they wanted to research.

Findings also provide insight into the importance of collaboration and fostering a community of scholars. These findings support previous research that demonstrates that creating a shared space wherein ideas, frustrations and support, can be realized for marginalized youth. Authors (Arvaja et al. 2007; Barab et al. 2001) note the connection between the individual and her/his environment, and the positive influence of peer interaction, on the stimulation of knowledge construction. Asserting the benefits gained through participating in a community of scholars, Van Boxtel et al. (2000) offer the following:

An important explanation of the positive results of collaborative learning may be the notion that social interaction stimulates elaboration of conceptual knowledge. In a collaborative learning situation, students will verbalize their understanding (p. 313). 
The students learned that what can be derived from sharing space with their peers during the process of pursuing their research efforts, was an opportunity to reason through some of the challenges and conflicts they experienced as a result of participating in this process of critical global leadership development. Additionally, the concept of collaboration provided the students valuable insight into the meaning of being "in conversation" with other individuals (across generations). Having this conceptual knowledge served to further solidify their global leadership development. Praxis gained at the global level as articulated by Ginwright and Cammarota (2002), is the culmination of when youth understand the centrality of race and racism in societal contexts, the unique commonality of the experiences that they bear, and the commitment that they have for working towards socially just outcomes in their communities (Akom 2009). However, contemporary educational approaches to "teach to the test", leave little room to alter curriculums (Stewart and Boggs 2018) that invite renditions of everyday life and critical social analysis into academic settings. However, Akom (2009) asserts that this form of restructuring is necessary for "eradicating racialized opportunity gaps in achievement and for creating educational spaces that ameliorate the life and death issues that many of our youth face on a daily basis" (p. 53).

\section{Implications and Conclusions}

Formal and informal learning environments, particularly for minoritized, urban students must leverage the strengths that students bring to the educational context by utilizing their culturally sustaining pedagogies (Paris 2012) and their life experiences as a place to launch their own social analysis and critical perspectives. Sadly, urban youth often do not have access nor the opportunity to receive transformative critical globalization education. Curriculum and programs focused on global education and leadership development should not be reserved for a select few such as historically "majoritized" students who have access to IB and AP curriculum. Rather, ALL students should have access to a critical globalization education and youth-led critical research experiences such as this one. Lapayese (2003) contends that such a process of critical globalization education "is only potentially liberating...its success depends upon the ability of those students who have been empowered to transcend the previously oppressive power relations. This requires that the students envision, develop, and function within new emancipatory patterns of organization in which the human dignity of everyone is protected and promoted" (p. 500). If and when schools, particularly urban schools serve as sites and enclaves where critical and liberatory perspectives are not themselves marginalized, rather central and foundational to the project of schooling in all contexts, we will begin to see transformative shifts towards what we believe could be sustained justice (Tuck and Yang 2018).

What cannot become lost in this regard is the consideration that today's youth are digital natives. Young people representing the Millennial and Me Generations (Allen et al. 2015; Lippman et al. 2009), were born into a society influenced by the omnipresence of technology, and the access to the world that it affords (Twenge and Campbell 2008). Email, text messages, and Facetime technologies, have created 
a hyper-connectivity that youth of today have known their entire lifetime (Mesch 2012). According to Mesch (2012), the "network effect", the diffusion of social media in daily interactions based on the pervasive use of cell phone and Internet technology, "has become an integral part of youth culture" (p. 98). Through technology, young people have been able to gain a broader perspective of issues that impact not only their local communities, but global communities as well, based upon increased exposure to different cultures, ethnicities and social issues (Mesch 2012). Tate (2001) advises that the way in which educators utilize technology within their class settings, can expand the opportunity for students to develop global leadership capacities.

Based on our findings and the existing research on global leadership development, this study has implications for urban schools and communities both inside and outside of our Northeast location, particularly locales that may be grappling with globalization in some form or fashion. Therefore, we submit to the field for instigation what we believe could support the replication of such a program, what we consider to be the C4Cs of critical global leadership development (note the first $\mathrm{C}$ stands for critical): Critical Competency, Critical Contingency, Critical Curriculum, and Critical Capacity.

\section{Critical Competency, Contingency, Curriculum and Capacity}

Preparing youth to contend with issues of justice requires not only that they gain exposure and practice with grappling with these issues (Allen-Handy et al. 2019; Sung and Allen-Handy 2019; Sung and Coleman 2019), but also that they possess the capacity for said issues to resonate within. Among some of the foundational characteristics highlighted in extant global leadership literature,- - the competency of empathy (Jokinen 2005; Kets de Vries and Florent-Treacy 2002), students from urban communities, particularly those of racial, economic and social marginalization, are uniquely situated to apply empathy towards circumstances of global import. By and large, empathy is not enough to transform systems and structures of oppression, injustice, and White supremacy (Davies 2008), and therefore, there is a need to provide students with many opportunities for critical social analysis and critical consciousness building. Cultivating self-awareness and inquisitiveness about how the individual fits within the larger framework of society with elements of competency leadership theory, works in conjunction with SJYD theory, which seeks to employ critical consciousness into social action (Murray and Milner 2015). It is therefore appropriate that the development of global leadership in youth does not reside solely within one theory, but draws from a variety of disciplines and frameworks, as the term global implies.

The unique ways in which the nuances of place and space impact the development of critical global leadership development will determine the characteristics needed within a particular context (Morrison 2000). This perspective draws from contingency models of leadership. However, there must be opportunities wherein formalized instruction (i.e. critical curriculum) can deepen the understanding of the global implications of an individualized experience. The UN Sustainable Development Goals can be contributory 
in developing curricula where technology presides as the bedrock of instruction, and provides creative opportunities to offer students expansive content that is current, while remaining culturally relevant. Exposure to world conditions through the use of technology, can augment standardized school curricula, bolster the understanding of world issues within the context of their local communities and provide the needed capabilities to build global leaders. Through an interdisciplinary approach, and the synthesis of business, social, and educational models, global leadership development has the potential to transcend formal classroom parameters to become accessible to students who would not traditionally internalize their potential for global leadership or envision themselves as leaders in a global context.

In sum, the UN SDGs in and of themselves are not enough to catapult urban youth into a deep critical social analysis of injustices around the globe. Rather, the goals must be situated in a context that examines the social, historical, political, and economical implications of colonization, racism, prejudice, violence, and war across ideologies and other differences. In doing so within the Urban Youth Scholars program, we were able to develop a two-year program with $100 \%$ student retention in exploration of global injustice and the UN SDGs. What was hoped for in the program, was to develop transformative global youth leaders who are not only local leaders, but global leaders. In a world where urban youth face a myriad of social, environmental, and educational ills not of their own making, they need and deserve educational spaces to employ a critical analysis to their own injustices. Unfortunately, these spaces are not made readily available within school contexts. As educators, we have to ask ourselves why is this so and how do we continue to reject neoliberal views of schooling for urban minoritized children so that they can develop global leadership characteristics and competencies for not just one form of social justice, but for "just justice" (as Gloria Ladson-Billings so eloquently stated in her March 5, 2015 keynote address after being awarded the American Education Research Association Social Justice Award). What could a just justice perspective include? We believe it could include justice around all the UN SDGs so therefore health justice, peace justice, environmental justice, social justice, gender justice, and educational justice to name just a few. Jacob depicts his ongoing internal dialogue about becoming a global leader that beautifully highlights this point:

As a global leader, I think I lack a certain initiative that I'm working on. I think I could probably stand to be more outspoken about things than I am. But there's that small fear of being the obnoxious social justice guy who's always just spewing about nothing in particular.

The fact that he claimed himself to be a "social justice guy" actualizes what we aspired to cultivate in the Urban Youth Scholars program...to cultivate a new generation of urban youth just justice global leaders, not so much justice for just us (me and mine) global leaders (Hughes 2011), but for everyone. As the world collectively tackles the global pandemic of COVID-19, we find ourselves in urgent need of critical global leadership. Who better to lead the way than our youth? A critical globalization education is needed now more than ever. 


\section{References}

Adler, N. J., \& Bartholomew, S. (1992). Managing globally competent people. The Executive, 6(3), 52-65.

Akom, A. A. (2009). Critical hip hop pedagogy as a form of liberatory praxis. Equity and Excellence in Education, 42(1), 52-66. https://doi.org/10.1080/10665680802612519.

Akom, A. A., Cammarota, J., \& Ginwright, S. (2008). Youthtopias: Towards a new paradigm of critical youth studies. Youth Media Reporter, 2(4), 1-30.

Allen, A., Scott, L. M., \& Lewis, C. W. (2013). Racial microaggressions and African American and Hispanic students in urban schools: A call for culturally affirming education. Interdisciplinary Journal of Teaching and Learning, 3(2), 117-129.

Allen-Handy, A., \& Thomas-EL, S. L. (2018). Be (com) ing critical scholars: The emergence of urban youth scholar identities through research and critical civic praxis. Urban Education, 0042085918814589

Allen-Handy, A., Thomas-EL, S. L., Bhuiyan, T., Carroll, X., Karlen, E., Medlock, I., Weeks, I. (2019). Urban youth/international scholars: Critical solutions in support of the U.N. Sustainable Development Goals. In P. A. Robinson, A. Allen-Handy, A. Bryant, C. W. Lewis (Eds.), Global perspectives on issues and solutions in urban education (pp. 249-283). Charlotte, NC: Information Age.

Arvaja, M., Salovaara, H., Häkkinen, P., \& Järvelä, S. (2007). Combining individual and group-level perspectives for studying collaborative knowledge construction in context. Learning and Instruction, $17(4), 448-459$.

Baldridge, B. J., Beck, N., Medina, J. C., \& Reeves, M. A. (2017). Toward a new understanding of community-based education: The role of community-based educational spaces in disrupting inequality for minoritized youth. Review of Research in Education, 41(1), 381-402.

Barab, S. A., Hay, K. E., \& Yamagata-Lynch, L. C. (2001). Constructing networks of action-relevant episodes: An in situ research methodology. The Journal of the Learning Sciences, 10(1-2), 63-112.

Bartlett, C. A., \& Ghoshal, S. (1987). Managing across borders: New strategic requirements. Sloan Management Review, 28, 7-17.

Bartlett, C. A., \& Ghoshal, S. (1992). What is a global manager? Harvard Business Review, 70(5), $124-132$.

Baumol, W. J., Blackman, S. A. B., \& Wolff, E. N. (1989). Productivity and American leadership: The long view. Cambridge, MA: MIT Press.

Bird, A., \& Mendenhall, M. E. (2016). From cross-cultural management to global leadership: Evolution and adaptation. Journal of World Business, 51(1), 115-126.

Brake, T. (1997). The global leader. Critical factors for creating the world class organization. Chicago, IL: Irwin Professional Publishing.

Bronfenbrenner, U. (1979). The ecology of human development. Cambridge, MA: Harvard University Press.

Burnham, J. B. (1993). Changes and challenges: The transformation of the US steel industry. Saint Louis, MO: Center for the Study of American Business. Washington University.

Burns, D., Harvey, B., \& Aragón, A. O. (2012). Introduction: Action research for development and social change. IDS Bulletin, 43(3), 1-7.

Cammarota, J. (2011). Blindsided by the avatar: White saviors and allies out of Hollywood and in education. Review of Education, Pedagogy, and Cultural Studies, 33(3), 242-259.

Cammarota, J., \& Fine, M. (2008). Revolutionizing education: Youth participatory action research in motion. New York: Routledge.

Caraballo, L., Lozenski, B. D., Lyiscott, J. J., \& Morrell, E. (2017). YPAR and critical epistemologies: Rethinking education research. Review of Research in Education, 41(1), 311-336.

Carl, J. (2009). Industrialization and public education: Social cohesion and social stratification. In International handbook of comparative education (pp. 503-518). Springer, Dordrecht.

Checkoway, B. (2011). What is youth participation? Children and Youth Services Review, 33(2), 340345. https://doi.org/10.1016/j.childyouth.2010.09.017.

College Entrance Examination Board. (2012). The 8th annual ap @ report to the nation. Retrieved May 12, 2018 from https://secure-media.collegeboard.org/digitalServices/public/pdf/ap/rtn/AP-Repor t-to-the-Nation.pdf.

Conner, J., \& Rosen, S. M. (2016). Contemporary youth activism: Advancing social justice in the United States. Santa Barbara: Praeger. 
Corbin, J., \& Strauss, A. (2008). Techniques and procedures for developing grounded theory. In Basics of qualitative research, 3rd edn.Thousand Oaks, CA: Sage.

Costanza, R., Daly, L., Fioramonti, L., Giovannini, E., Kubiszewski, I., Mortensen, L. F., et al. (2016). Modelling and measuring sustainable wellbeing in connection with the UN Sustainable Development Goals. Ecological Economics, 130(1), 350-355.

Creswell, J. W. (2013). Qualitative inquiry and research design: Choosing among five approaches. Thousand Oaks, CA: Sage Publications.

Culross, R., \& Tarver, E. (2011). A summary of research on the International Baccalaureate Diploma Programme: Perspectives of students, teachers, and university admissions offices in the USA. Journal of Research in International Education, 10(3), 231-243.

Davies, L. (2008). Global citizenship in education. In M. Bajaj (Ed.), Encyclopedia of peace education. New York: Columbia University.

De Lissovoy, N. (2010). Decolonial pedagogy and the ethics of the global. Discourse: Studies in the Cultural Politics of Education, 31(3), 279-293.

De Lissovoy, N. (2011). Pedagogy in common: Democratic education in the global era. Educational Philosophy and Theory, 43(10), 1119-1134.

De Lissovoy, N. (2012). Education and violation: Conceptualizing power, domination, and agency in the hidden curriculum. Race Ethnicity and Education, 15(4), 463-484.

De Lissovoy, N., \& Brown, A. L. (2013). Antiracist solidarity in critical education: Contemporary problems and possibilities. The Urban Review, 45(5), 539-560.

Dolan, T., Christens, B. D., \& Lin, C. (2015). Combining youth organizing and youth participatory action research to strengthen student voice in education reform. Teachers College Record, 117(13), 153-170.

Dorfman, P. (1996). International and cross-cultural leadership. In B. J. Punnett \& O. Shenkar (Eds.), Handbook for international management research (pp. 267-349). Cambridge, MA: Blackwell.

Eidoo, S., Ingram, L. A., MacDonald, A., Nabavi, M., Pashby, K., \& Stille, S. (2011). "Through the kaleidoscope": Intersections between theoretical perspectives and classroom implications in critical global citizenship education. Canadian Journal of Education, 34(4), 59-84.

Finn, J. L., \& Checkoway, B. (1998). Young people as competent community builders: A challenge to social work. Social work, 43(4), 335-345.

Flanagan, C., \& Levine, P. (2010). Civic engagement and the transition to adulthood. The Future of Children, 20(1), 159-179. https://doi.org/10.1353/foc.0.0043.

Freire, P. (1970). Pedagogy of the oppressed. New York: Bloomsbury Publishing.

Friedman, T. (2007). The world is flat 3.0. A world history. New York: Picador/Farrar, Straus and Giroux.

Gay, G. (2010). Culturally responsive teaching: Theory, research and practice. New York: Teachers College Press.

Ginwright, S. A. (2004). Black in school: Afrocentric reform, urban youth and the promise of hip hop culture. New York: Teachers College Press.

Ginwright, S., \& Cammarota, J. (2002). New terrain in youth development: The promise of a social justice approach. Social Justice, 29(4 (90)), 82-95.

Ginwright, S., \& Cammarota, J. (2007). Youth activism in the urban community: Learning critical civic praxis within community organizations. International Journal of Qualitative Studies in Education, 20(6), 693-710.

Ginwright, S., Cammarota, J., \& Noguera, P. (2005). Youth, social justice, and communities: Toward a theory of urban youth policy. Social Justice, 32(3 (101)), 24-40.

Goleman, D. (1998). What makes a leader? Harvard Business Review, 76(6), 93-103.

Gregersen, H. B., Morrison, A. J., \& Black, J. S. (1998). Developing leaders for the global frontier. Sloan Management Review, 40, 21-32.

Hallett, R. E., \& Venegas, K. M. (2011). Is increased access enough? Advanced placement courses, quality, and success in low-income urban schools. Journal for the Education of the Gifted, 34(3), 468-487.

Harvey, M., \& Buckely, R. M. (2002). Assessing the conventional wisdoms of management for the 21st century organization. Organizational Dynamics, 30(4), 368-378.

Henderson, D. X., Washington, K., Hamit, S., Ford, S. J., \& Jenkins, K. (2018). Modeling resilience in an alternative education context. The Urban Review, 50(4), 675-692.

Hill, I. (2012). An international model of world-class education. The international baccalaureate. Prospect, 42(3), 341-359. https://doi.org/10.1007/s11125-012-9243-9. 
Hill, I., \& Saxton, S. (2014). The International Baccalaureate (IB) programme: An international gateway to higher education and beyond. Higher Learning Research Communications, 4(3), 42.

Hipolito-Delgado, C. P., \& Zion, S. (2017). Igniting the fire within marginalized youth: The role of critical civic inquiry in fostering ethnic identity and civic self-efficacy. Urban Education, 52(6), 699-717.

Howard, T. C., \& Milner, H. R. (2014). Teacher preparation for urban schools. In Handbook of urban education (pp. 199-216).

Hughes, S. A. (2011). Justice for all or justice for just us? Toward a critical race pedagogy of hope through Brown in urban education. Urban Education, 46(1), 99-110.

Hull, G., Zacher, J., \& Hibbert, L. (2009). Youth, risk, and equity in a global world. Review of Research in Education, 33(1), 117-159. https://doi.org/10.3102/0091732X08327746.

Iwasaki, Y. (2016). The role of youth engagement in positive youth development and social justice youth development for high-risk, marginalised youth. International Journal of Adolescence and Youth, 21(3), 267-278.

Jensen, M. C. (1993). The modern industrial revolution, exit, and the failure of internal control systems. The Journal of Finance, 48(3), 831-880.

Jokinen, T. (2005). Global leadership competencies: a review and discussion. Journal of European Industrial Training, 29(3), 199-216.

Karvelis, N. (2018). Race, class, gender, and rhymes: Hip-hop as critical pedagogy. Music Educators Journal, 105(1), 46-50. https://doi.org/10.1177/0027432118788138.

Kenway, J., \& Bullen, E. (2008). The global corporate curriculum and the young cyberflâneuras global citizen. In: Youth moves (pp. 31-46). New York, NY: Routledge.

Kets de Vries, M. F. R., \& Florent-Treacy, E. (2002). Global leadership from a to z: Creating high commitment organizations. Organizational Dynamics, 295(309), 1-16.

Kirshner, B. (2015). Youth activism in an era of education inequality. New York: New York University Press.

Ladson-Billings, G. (1995). Toward a theory of culturally relevant pedagogy. American Educational Research Journal, 32(2), 465.

Ladson-Billings, G. (2006). From the achievement gap to the education debt: Understanding achievement in U.S. schools. Educational Researcher, 35(7), 3-12.

Lapayese, Y. V. (2003). Toward a critical global citizenship education. Comparative Education Review, 47(4), 493-501.

Leonardo, Z., \& Hunter, M. (2007). Imagining the urban: The politics of race, class, and schooling. In W. T. Pink \& G. W. Noblit (Eds.), International handbook of urban education (pp. 779-802). New York, NY: Springer.

Lieblich, A., Tuval-Mashiach, R., \& Zilber, T. (1998). Narrative research: Reading, analysis, and interpretation (Vol. 47). Thousand Oaks: Sage.

Lipman, P. (2013). The new political economy of urban education: Neoliberalism, race, and the right to the city. London: Taylor \& Francis.

Lippman, S., Bulanda, R. E., \& Wagenaar, T. C. (2009). Student entitlement: Issues and strategies for confronting classroom and beyond. College Teaching, 57(4), 1-12.

Longo, N. V., \& McMillan, J. (2015). Educating for global leadership: A north-south collaboration. New Directions for Student Leadership, 2015(148), 73-86.

Margon, S. (2018). Giving up the high ground: America's retreat on human rights. Foreign Affairs, 97, 39.

Mendenhall, M. E. (2006). The elusive, yet critical challenge of developing global leaders. European Management Journal, 24(6), 422-429.

Mendenhall, M. E., Reiche, B. S., Bird, A., \& Osland, J. S. (2012). Defining the "global" in global leadership. Journal of World Business, 47(4), 493-503.

Mesch, G. S. (2012). Technology and youth. New directions for youth development, 2012(135), 97-105.

Mikander, P. (2016). Globalization as continuing colonialism: Critical global citizenship education in an unequal world. JSSE-Journal of Social Science Education, 15, 70-79.

Miller, D. C., \& Salkind, N. J. (2002). Handbook of research design and social measurement. Thousand Oaks: Sage.

Milner, H. R., IV. (2012). But what is urban education? Urban Education, 47(3), 556-561.

Mittelman, J. H. (2004). What is critical globalization studies? International Studies Perspectives, 5(3), $219-230$. 
Morrison, A. J. (2000). Developing a global leadership model. Human Resource Management, 39(2-3), $117-131$.

Morrison, T. (2019). The source of self-regard: Selected essays, speeches, and meditations. New York: Vintage.

Murray, I. E., \& Milner, H. R. (2015). Toward a pedagogy of sociopolitical consciousness in outside of school programs. Urban Review, 47(5), 893-913.

Myers, J. P. (2006). Rethinking the social studies curriculum in the context of globalization: Education for global citizenship in the US. Theory and Research in Social Education, 34(3), 370-394.

Myers, J., \& Zaman, H. (2009). Negotiating the global and national: immigrant and dominant culture adolescents' vocabularies of citizenship in a transnational world. Teachers College Record, 111, 2589-2625.

O’Donoghue, J., Kirshner, B., \& McLaughlin, M. (2002) Introduction: Moving youth participation forward. In Youth participation: Improving institutions and communities (New Directions in Youth Development, No. 96) (pp. 15-26). San Francisco: Jossey-Bass.

O’Leary, Z. (2007). Phenomenology. In Z. O’Leary (Ed.), The social science jargon buster (pp. 193194). London: SAGE Publications Ltd. https://doi.org/10.4135/9780857020147.

Oliveira Andreotti, V. (2014). Soft versus critical global citizenship education. In S. McCloskey (Ed.), Development education in policy and practice (pp. 21-31). London: Palgrave Macmillan.

Osland, J. S., Bird, A., \& Oddou, G. (2012). The context of expert global leadership. In Advances in global leadership (Vol. 7, pp. 107-124). Emerald Group Publishing Limited.

Ozer, E. J., Ritterman, M. L., \& Wanis, M. G. (2010). Participatory action research (PAR) in middle school: Opportunities, constraints, and key processes. American Journal of Community Psychology, 46(1-2), 152-166.

Paris, D. (2012). Culturally sustaining pedagogy: A needed change in stance, terminology, and practice. Educational Researcher, 41(3), 93-97.

Parker, W., Ninomiya, A., \& Cogan, J. (1999). Educating world citizens: Toward multinational curriculum development. American Educational Research Journal, 36(2), 117-145.

Petriglieri, G. (2016). In defense of cosmopolitanism. Harvard Business Review, 15. Retrieved from https ://hbr.org/2016/12/in-defense-of-cosmopolitanism.

Powers, C., \& Allaman, E. (2012). How participatory action research can promote social change and help youth development. In Berkman Center Research Publication (2013-10).

Rapoport, A. (2010). We cannot teach what we don't know: Indiana teachers talk about global citizenship education. Education, Citizenship and Social Justice, 5(3), 179-190.

Reiche, B. S., Bird, A., Mendenhall, M. E., \& Osland, J. S. (2017). Contextualizing leadership: a typology of global leadership roles. Journal of International Business Studies, 48(5), 552-572.

Sachs, J. (2008). Common wealth: Economics for a crowded planet. London: Penguin.

Shiva, V. (1998). The greening of global reach. In G. Thuatail, S. Dalby, \& P. Routledge (Eds.), The geopolitics reader (pp. 231-236). NY: Routledge.

Soja, E. W. (1994). Thirdspace: Journeys to Los Angeles and other real and imagined places. Cambridge, MA: Blackwell.

Spring, J. H. (2016). American education. Boston: McGraw-Hill.

Srivastava, P., \& Hopwood, N. (2009). A practical iterative framework for qualitative data analysis. International Journal of Qualitative Methods, 8(1), 76-84.

Steinberg, S. R. (2014). Redefining the notion of youth: Contextualizing the possible for transformative youth leadership. In A. Ibrahim \& S. R. Steinberg (Eds.), Critical youth studies reader (pp. 426433). New York, NY: Peter Lang.

Stewart, T. T., \& Boggs, G. L. (2018). Urban teachers' online dissent produces cultural resources of relevance to teacher education. The Urban Review, 51(2), 183-200.

Sung, K. (2014) 'Hella ghetto!': (dis)locating race and class consciousness in youth discourses of ghetto spaces, subjects and schools. Race Ethnicity and Education, 18(3), 363-395.

Sung, K., \& Allen-Handy, A. (2019). Contradictory origins and racializing legacy of the 1968 Bilingual Education Act: Urban schooling, anti-blackness, and Oakland's 1996 Black English language education policy. University of Maryland Law Journal on Race, Religion, Gender, \& Class, 44

Sung, K., \& Coleman, N. (2019). Framing critical race theory and methodologies. Research Methods for Social Justice and Equity in Education (pp. 45-57). New York: Palgrave Macmillan.

Taliaferro, J. D., \& DeCuir-Gunby, J. T. (2008). African American educators' perspectives on the advanced placement opportunity gap. The Urban Review, 40(2), 164-185. 
Tate, W. (2001). Science education as a civil right: Urban schools and opportunity-to-learn considerations. Journal of Research in Science Teaching: The Official Journal of the National Association for Research in Science Teaching, 38(9), 1015-1028.

Thornton, S. J. (2005). Incorporating internationalism into the social studies curriculum. In Educating citizens for global awareness (pp. 81-92).

Tuck, E., \& Yang, K. W. (2018). Toward what justice? Describing diverse dreams of justice in education. New York, NY: Routledge.

Twenge, J. M., \& Campbell, W. K. (2008). Increases in positive self-views among high school students: Birth-cohort changes in anticipated performance, self-satisfaction, self-liking, and self-competence. Psychological Science, 19(11), 1082-1086.

United Nations. (2015). Resolution adopted by the general assembly on 25 September 2015. Retrieved from https://www.un.org/ga/search/view_doc.asp?symbol=A/RES/70/1\&Lang=E.

United Nations. (2020, February 8). About the sustainable development goals. Welcome to the United Nations. https://www.un.org/sustainabledevelopment/sustainable-development-goals/.

Usher, K., \& Jackson, D. (2014). Phenomenology. In J. Mills \& M. Birks (Eds.), Qualitative methodology (pp. 181-198). London: SAGE Publications Inc. https://doi.org/10.4135/9781473920163.

Van Boxtel, C., Van der Linden, J., \& Kanselaar, G. (2000). Collaborative learning tasks and the elaboration of conceptual knowledge. Learning and Instruction, 10(4), 311-330.

Watts, R. J., \& Hipolito-Delgado, C. P. (2015). Thinking ourselves to liberation? Advancing sociopolitical action in critical consciousness. The Urban Review, 47(5), 847-867.

Weiner, M. F. (2012). Towards a critical global race theory. Sociology Compass, 6(4), 332-350.

Zeldin, S., Gauley, J., Krauss, S. E., Kornbluh, M., \& Collura, J. (2017). Youth-adult partnership and youth civic development: Cross-national analyses for scholars and field professionals. Youth and Society, 49(7), 851-878. https://doi.org/10.1177/0044118X15595153.

Publisher's Note Springer Nature remains neutral with regard to jurisdictional claims in published maps and institutional affiliations. 